\title{
The Relationship Between the Entrepreneurship Characteristics and Metacognitive Awareness Levels of Pre-service Teachers
}

\author{
Burcu Duman \\ Correspondence: Burcu Duman, Bartin University, Faculty of Education, Turkey. \\ Received: March 5, 2018 \\ doi:10.11114/jets.v6i5.3080 \\ Accepted: April 2, $2018 \quad$ Online Published: April 9, 2018 \\ URL: https://doi.org/10.11114/jets.v6i5.3080
}

\begin{abstract}
The purpose of this study is to determine the relationship between the entrepreneurship characteristics and metacognitive awareness levels of pre-service teachers. Qualitative research method is used in this study and the study is designed as a relational survey. The sample of the study was 441 pre-service teachers studying at the faculty of education of a public university in Turkey during the spring semester in 2015-2016 academic year. Random sampling was used to determine the sample group. The instruments used to collect the data in the study were "Metacognitive Awareness Scale for Pre-service Teachers (MASP)" developed by Duman (2013) and "Entrepreneurship Scale for University Students (ESUS)" developed by Yılmaz and Sünbül (2009). SPSS-22 package program was used to analyze the collected data. In determining the relationships between the scores from MASP and ESUS scales, pearson product-moment correlation analysis was conducted. In determining MASP's prediction of the scores from the ESUS scale multiple linear regression analysis was used. The results indicated a positive relationship at medium level between entrepreneurship characteristics and metacognitive awareness levels of pre-service teachers $(\mathrm{r}=.565 \mathrm{p}<0.01)$. In addition, there are significant positive relationships between entrepreneurship characteristics and all sub-scales of MASP. It was found that the metacognitive awareness levels of pre-service teachers predicted their entrepreneurship characteristics at a rate of $43 \%$. It is possible to say that activities towards improving metacognitive awareness could have positive impacts on entrepreneurship.
\end{abstract}

Keywords: entrepreneurship, metacognition, metacognitive awareness, pre-service teacher

\section{Introduction}

The Modern trends in education focus on student-centered and constructive approach rather than the traditional teacher-centered approach (Douville \& Pugalee 2003, 62). Defined as "systematic thinking" and "learning to learn" Gelen $(2004,6)$ the concept of metacognition emphasizes one's awareness in thinking and learning. Metacognition is based on the hypothesis that support "When one comprehends how his/her cognitive processes work, s/he can control them and reorganize them for more efficient learning." (Ülgen, 1997). This premise makes metacognition important in learning (Yurdakul \& Demirel, 2011, 72). The concept of metacognition was used by Flavell in 1976 for the first time based on developmental psychology and meta-memory studies. Flavell explains metacognition as structuring the inputs and letting them in the memory consciously; scanning the data in the memory and finding out the requested ones; arranging the data in the memory and being aware of those stored data (Flavell, 1979, 906-911). Metacognition consists of skills such as prediction, planning, monitoring and evaluation on one's own mental activities (Brown, 1980). Metacognition is also the ability to reflect, understand and control one's learning (Schraw, 1998). According to Livingstone, (2003, 3) and Blakey and Spence (1990, 1), metacognition is "thinking about thinking". In short, metacognition can be expressed as the awareness and control of one's own thinking process (Flavell, 1979; Wellman, 1985, 1; Hacker \& Dunlosky, 2003; Jager, Jensen \& Reezigt, 2005; Baker, 2010).

As Demircioğlu $(2008,3)$ states, metacognition is effective in creativity, verbal comprehension, reading comprehension, problem solving, attention, memory, social cognition, self-control and self-education. According to Larkin (2000, 2), metacognition is important in the development of critical thinking and self-confident learning. Moreover, Kuiper (2002, 79) claims that when metacognition is obtained once, it supports reflective thinking, gives a sense of responsibility and increases self-confidence in practical decision-making for a lifetime. Demircioğlu $(2008,4)$ emphasizes that metacognitive experiences increase success and learning by drawing attention to the importance of setting the learning environment to enhance knowledge and skills. As stated by Hartman \& Stenberg $(1993,410)$, teachers should play two roles aimed at improving metacognitive knowledge and skills, and reflecting metacognition on their curriculum. Heirdsfield (2003; Cite in. Demircioğlu, 2008, 10) indicates that it is necessary to focus on the role of teachers in 
increasing the awareness of students. Taking into consideration the fact that metacognition awareness levels of teachers are important factors in development of students' metacognitive skills, awareness levels of pre-service teachers also become significant (Deniz et al., 2014, 308).

As a matter of fact, there are various studies on determining the metacognitive awareness levels of pre-service teachers (Tüysüz, Karakuyu \& Bilgin, 2008; Aydın \& Coşkun, 2011; Özsoy \& Gunindi, 2011; Sezgin \& Akkaya, 2012; Baysal et al. 2013; Tuncer \& Kaysi, 2013; Deniz et al. 2014; Bakioğlu et al. 2015; Gül, Özay-Köse \& Sadi Y1lmaz, 2015). These studies have generally investigated the differentiation of metacognitive awareness in terms of variables such as gender, field of study and grade. There are also some studies in which the relationships between metacognitive awareness of pre-service teachers and professional and academic self-efficacy, epistemological beliefs, mathematics anxiety levels, attitudes towards technology, problem solving and critical thinking have been examined (Durdukoca, 2012; Bedel \& Çakır, 2013; Tunca \& Alkın Şahin, 2014; Semerci \& Elaldı, 2014; Bakioğlu, Alkış Küçükaydın \& Karamustafaoğlu, 2015; Kacar \& Sarıçam, 2015; Kılınç \& Uygun, 2015; Yokuş \& Yürüdür, 2015; Sırmacı \& Taş, 2016; Karataş, 2017).

It is seen that metacognitive awareness is investigated by being associated to various subjects and concepts, and that this kind of studies continue to expand. One of the subjects examined together with metacognitive awareness is entrepreneurship (Haynie, Gregorie, \& Shepherd, 2004; Mitchell et al., 2005; Haynie \& Shepherd, 2007; Kleitman, Stankov, 2007; Vrugt \& Oort, 2008; Ling et al. 2011; Haynie, Shepherd \& Patzelt, 2012). Entrepreneurship is to create value by bringing novelty, making use of creative skills, or in other ways like finding new products, services, sources, technologies or markets (Bird, 1989). As stated in another definition, it is "an activity of detecting an opportunity and creating organization to seize it" (Mueller \& Thomas, 2000). Entrepreneurship is a process that creates value for individuals and society, that gives answers to economic opportunities, or that is put forward by the individuals who create economic opportunities, and that leads to changes in the economic system through the innovations it brings (Muzyka, Koning \& Churchill, 1995). Successful entrepreneurs have common features such as the ability to take risks or responsibilities, a dynamic personality, being open to innovation, change and transformation, ambition and passion for growth, focus on the final accomplishment (Oktay, 1996). In addition, they have creative thinking skills, desire to work hard, the ability to express oneself verbally and in written, rich subconscious and imagination, flexible and tolerant treatment, love and motivation for work, sincerity, reliability, congeniality, sense of humour, management skills and leadership ability, personal vision and mission, foresightedness and habit of seizing opportunities (Hisrich \& Peters, 1998).

Entrepreneurship is considered as a source for growth and competitive power. It has become an important agenda for universities and governments to promote entrepreneurship among students (Ling et al., 2011, 2). Entrepreneurship has become a characteristic aimed to be improved in people who are highlighted throughout the world (Ocak \& Su, 2016, 5). Therefore, it is a necessity to increase the number of entrepreneurship activities, to create environments where entrepreneurs express themselves, and to make entrepreneurship internalized in every step of education (Pan \& Akay, $2015,128)$. It is a part of the education system to raise entrepreneurs. Numerous studies carried out have revealed that entrepreneurship is an important component in higher education (Pan \& Akay, 2015, 128). Students at the faculty of education are also expected to have "entrepreneur" characteristics and approaches as a result of the increasing number of private enterprise and business in the education sector (Ocak \& Su, 2016, 6). An entrepreneurial generation will be possible with teachers and pre-service teachers have entrepreneurial personality and approaches. In other words, it is thought that pre-service teachers with entrepreneurial personality and approaches will play an important role in training future entrepreneurial individuals as teachers. Thus, it is of great importance to be well informed about the entrepreneurship levels of pre-service teachers and to present the factors affecting these levels (Pan \& Akay, 2015, 128). The studies examining entrepreneurship levels of pre-service teachers draw attention to its importance (Çelik, 2014; Deveci \& Çepni, 2015; Pan \& Akay, 2015; Ocak \& Su, 2016; Memduhoğlu \& Şahin, 2017).

When metacognitive awareness and entrepreneurship, which matter to pre-service teachers, are considered together, it can be stated that cognitive psychology and metacognitive awareness have started to attract increasing attention in the context of entrepreneurship in scientific discussions (Ling et al., 2011, 2). The study by Ling et al. (2011) shows that metacognitive awareness is most developed in students who have high self-confidence, a desire for independence and a tendency to take risk; in short, who have entrepreneurship characteristics. Furthermore, it has been found that when both entrepreneurs and persons with high task - master skills present higher level of metacognitive awareness it is supporting the desired or optimal outcomes of their respective actions (Vrugt \& Oort, 2008). Mitchell et al. (2005) suggest that metacognitive awareness can be applied deliberately in an entrepreneur context. In addition, they assert that such a metacognitive view facilitates individuals' comprehension, control and that their entrepreneurship awareness reflects themselves, and it leads entrepreneurship specialization to be created (Mitchell, et al. 2005). According to the findings by Haynie and Shepherd (2007), cognitive adaptability which is essential within the context of entrepreneurship is increased by metacognition which improves the performance regarding an entrepreneur task. Aforementioned findings also suggest that individuals with entrepreneurship characteristics have high-level thinking skills and high metacognitive awareness. Therefore, this 
study aims to investigate the relationship between entrepreneurship characteristics and metacognitive awareness levels of pre-service teachers. In line with this purpose, answers were sought to the questions below:

- What is the correlation between entrepreneurship characteristics and metacognitive awareness levels of pre-service teachers?

- What is the predictive power of metacognitive awareness of pre-service teachers on entrepreneurship characteristics?

\section{Method}

In the study, relational survey method was used within the scope of quantitative research method. Relational survey is based on the measurement of two variables and identification of their relationship. Relational approach is effective in helping reach the research objectives regarding description and prediction (Christensen, Burke Johnson \& Turner, 2014).

\subsection{Population and Sample}

The population of the study consisted of pre-service teachers who studied at the faculty of education of a public university in Turkey during the spring semester of 2015-2016 academic year. The sample of the study comprised of 441 pre-service teachers who were selected from the population through random sampling.

\subsection{Participant Characteristics}

There were 280 females $(63,5 \%)$ and 161 males $(36,5 \%)$ in the sample. 222 of the pre-service teachers were freshman $(50,3 \%), 149$ of them were sophomore $(33,8 \%)$, and 70 of them were junior students $(15,9 \%)$. There were 42 pre-service teachers from Turkish Language Education (9,5\%), 94 from Primary School Education (21,3\%), 38 from Mathematics Education (8,6\%), 95 from Science Education (21,5\%), 92 from Social Sciences Education (20,9\%) and 80 from Religious Culture and Moral Knowledge Education departments (18,1\%).

\subsection{Instruments}

The instruments used in the study were "Metacognitive Awareness Scale for Pre-service Teachers (MASP)" developed by Duman (2013) and "Entrepreneurship Scale for University Students (ESUS)" developed by Yılmaz and Sünbül (2009). MASP scale is formed of 9 negative and 22 positive items. It has seven subdimensions as planning, awareness, inquiry, control, regulation, motivation, and evaluation. KMO value of the scale is 0,893 , the Bartlett test value is 4539,827 $(\mathrm{p}<0.05)$, and the Cronbach Alpha coefficient is 0,89 . The Cronbach Alpha coefficient was calculated as 0,915 for this study. "Entrepreneurship Scale for University Students" comprises of 36 items and one dimension. Its Kaiser-Meyer-Olkin (KMO) value was found to be 0,79 in the Principle Component Analysis. The Bartlett test value is 3482,21 ( $\mathrm{p}<0,01)$, and the Cronbach alpha coefficient is 0,9. The Cronbach Alpha coefficient was calculated as 0,937 for this study.

\subsection{Data Analysis}

SPSS-22 package program was used to analyze the collected data, and Pearson product moment correlation analysis was used to identify the relationships between the results of the metacognitive awareness and entrepreneurship scales. In addition, multilinear regression analysis was carried out to determine the MASP's prediction scores from the results from ESUS scale. In the analysis, the subdimensions of metacognitive awareness scale [(1) Planning, (2) Awareness, (3) Control, (4) Regulation, (5) Inquiry, (6) Motivation and (7) Evaluation] were taken as independent variable whereas the entrepreneurship was taken as dependent variable.

\section{Results}

The results of the correlation analysis carried out to determine the relationship between entrepreneurship characteristics and metacognitive awareness of pre-service teachers are given in Table 1.

Table 1. Relationship between entrepreneurship characteristics and metacognitive awareness of pre-service teachers

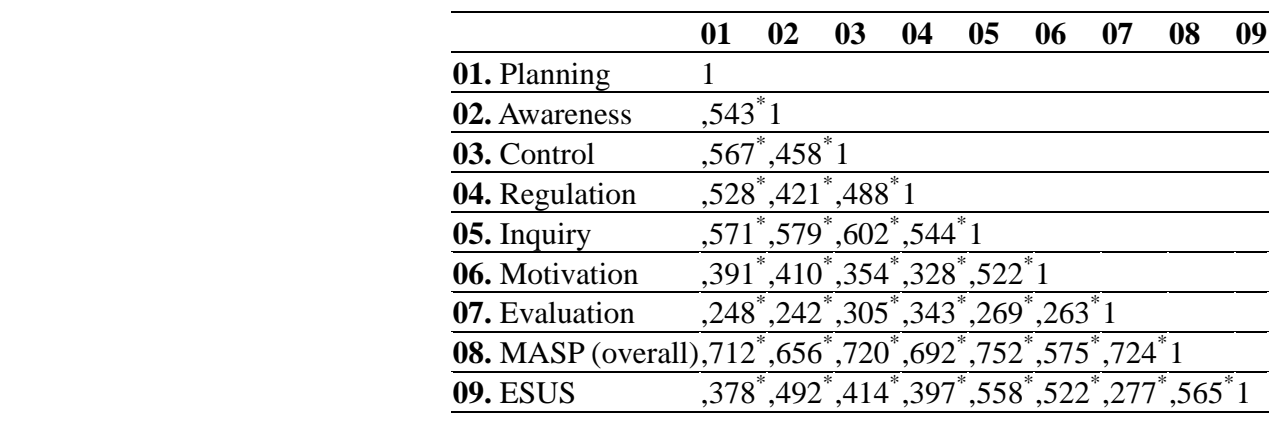


Between the entrepreneurship characteristics and metacognitive awareness levels of pre-service teachers, there is a significant positive relationship at medium level $(\mathrm{r}=, 565 \mathrm{p}<0.01)$. There are also significant positive relationships between entrepreneurship characteristics and all subdimensions of the metacognitive awareness scale. [ $\mathrm{r}$ planning=,378; $\mathrm{r}$ awareness $=, 492 ; \mathrm{r}$ control=,414; $\mathrm{r}$ regulation $=, 397 ; \mathrm{r}$ inquiry $=, 558 ; \mathrm{r}$ motivation=,552; $\mathrm{r}$ evaluation $=, 277 \mathrm{p}<0,01] \mathrm{In}$ subdimensions, the highest correlation was found to be with "inquiry". Furthermore, there are significant positive relationships at medium and high levels ranging from ,752 to ,575 between the overall MASP scale and its subdimensions. The results of the regression analysis on the prediction of entrepreneurship according to the variables; planning, awareness, control, regulation, inquiry, motivation and evaluation are given in Table 2.

Table 2. Results of the regression analysis on the prediction of entrepreneurship

\begin{tabular}{|c|c|c|c|c|c|c|}
\hline \multirow[b]{2}{*}{ Model } & \multicolumn{4}{|c|}{ Unstandardized Coefficients Standardized Coefficients } & \multicolumn{2}{|c|}{ Correlations } \\
\hline & $-\underline{B}$ & Std. Error & Beta & $-\mathrm{t}$ & Sig. Zero & Partial Part \\
\hline 1 (Constant) & 1,265 & 161 & & 7,834 &, 000 & \\
\hline Planning &,- 048 &, 037 &,--066 & $-1,298$ & $3,195,378$ &,$- 062-, 047$ \\
\hline Awareness & 149 &, 035 & 200 & $-4,208$ & $, 000,492$ & _, 198 \\
\hline Control &, 047 &, 039 &, 060 & 1,215 & $, 225,414$ & $, 058 \quad, 044$ \\
\hline Regulation &, 066 &, 042 &, 074 & 1,569 & $, 117,397$ & $, 075,057$ \\
\hline Inquiry &, 213 &, 049 &, 241 & 4,317 & $, 000,558$ & ,203, 157 \\
\hline Motivation & $\mathrm{n}, 178$ &, 028 & -278 & $-6,344$ & $, 000,522$ & _,292,231 \\
\hline Evaluation &, 042 &, 027 &, 063 & 1,590 & ,113,277 & ,076 058 \\
\hline
\end{tabular}

a. Dependent Variable: Entrepreneurship

$\mathrm{R}=0.652^{\mathrm{a}}, \mathrm{R}^{2}=0.425, \mathrm{~F}(7,433)=45,780, \mathrm{p}=0.000$, Durbin-Watson (D.W.) Statistic $=1,931$

The equation $(\mathrm{F}=45.780 ; \mathrm{p}<.01)$ for the prediction scores of MASP's subdimensions on ESUS is important. When $\mathrm{t}$-test results regarding the significance of regression coefficient are examined, it is found out that awareness, inquiry and motivation variables are significant predictors on entrepreneurship. Considering the standardized regression coefficient (Beta value), the fact that the beta value of motivation $(\beta=0.278)$ is higher than the others in terms of absolute value makes motivation the most important predictor in the model. In other words, motivation is the strongest predictor of entrepreneurship in this model. In predicting entrepreneurship; inquiry, awareness, regulation, planning, evaluation and control variables trace the motivation variable respectively. The multiple correlation coefficient $(R=0.652)$ which shows the relationship between dependent and independent variables is statistically important. The coefficient of determination indicates that the independent variables can explain approximately $43 \%$ of the alteration in the dependent variable. In other words, it is inferred that the $43 \%$ of the entrepreneurship's total variance depends on the mentioned variables $(\mathrm{R} 2=0.425$, $\mathrm{p}<.01)$. According to Cohen $(1988,412-413)$, these effect size results can be interpreted as (R2): .0196 - small, .1300 medium, and .2600 - large. These values reveal that MASP's subdimensions have a large effect size on entrepreneurship. The Durbin-Watson (DW) statistics was found to be 1.931, and Field (2009, 220-221) states that when DW statistics is about 2, it means there is no autocorrelation. This result indicates that there is no autocorrelation in error terms. The scatter plot of the regression analysis is given in Figure 1, and the histogram is in Figure 2.

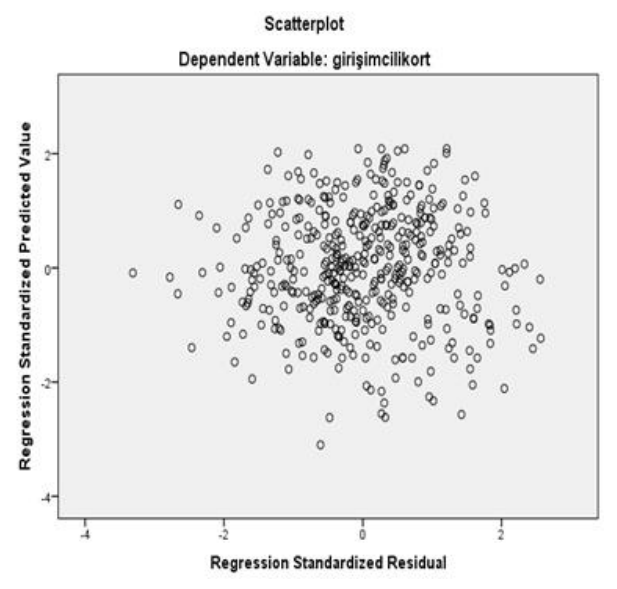

Figure 1. Scatter plot

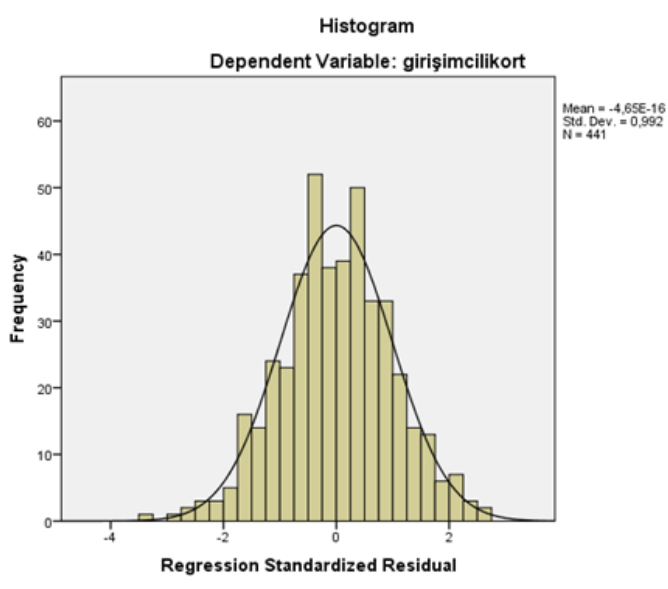

Figure 2. Histogram

Taking Figure 1 and 2 into consideration, it can be stated that there is a linear relationship between the predictor variables and dependent variables, and that the scores have a normal distribution in the application of regression 
analysis. According to the regression analysis results, the regression equation (the mathematical model) regarding the prediction of entrepreneurship is as below:

ENTREPRENEURSHIP $=1,265-$ 0,048 Planning + 0,149 Awareness +0.047 Control + 0,066 Regulation + 0,213 Inquiry $+0,178$ Motivation $+0,042$ Evaluation

\section{Discussion}

Metacognitive awareness critically affects decision-making in uncertain and risky situations like choosing to be an entrepreneur (Zhao, Seibert \& Hills, 2005; Barbosa, Gerhardt \& Kickul, 2007; Souitaris, Zerbinati \& Al-Laham, 2007). It is claimed that cognition, especially metacognition, provides strong theoretical basis for entrepreneurship studies which lack a solid theoretical and cognitive basis (Grégoire, Corbett \& McMullen, 2011; Mitchell et al, 2002); however, there is little information about the cognitive structures and processes necessary for learning entrepreneurship knowledge and skills (Pihie, Bagheri \&Sani $(2013,176)$. Therefore, it is considered essential to handle the relationship between entrepreneurship and metacognitive awareness through theoretical and applied research. When it is taken into consideration that it has become an important issue for universities and governments to encourage entrepreneurship among students (Ling et al, 2011, 2), it is worth investigating the relationship between entrepreneurship characteristics and metacognitive awareness levels of pre-service teachers who study at university to be able to educate the next generations. In this study, the correlation between entrepreneurship characteristics and metacognitive awareness level was surveyed, and the predictive power of metacognitive awareness on entrepreneurship characteristics was analyzed in order to examine the relationship between entrepreneurship characteristics and metacognitive awareness levels of pre-service teachers.

The research results indicated that there was a positive relationship at medium level between entrepreneurship characteristics and metacognitive awareness levels of pre-service teachers $(r=.565 \mathrm{p}<0.01)$. There were also significant positive relationships between entrepreneurship characteristics and all subdimensions of MASP. It can be inferred from this result that the increase in metacognitive awareness produces a positive effect on entrepreneurship. All the predictor variables (planning, awareness, control, regulation, inquiry, motivation and evaluation) explain the variance of entrepreneurship as a dependent variable by $43 \%$; in other words, it appears that $43 \%$ of the total variance belonging to entrepreneurship depends on the aforementioned variables $(\mathrm{R} 2=0.425, \mathrm{p}<.01)$. According to the standardized regression coefficient ( $\beta$ ), the relative importance order of the predictor variables on entrepreneurship is as follows: motivation, inquiry, awareness, regulation, planning, evaluation and control. These results show that metacognitive awareness is an important variable for predicting entrepreneurship. Thus, it can be stated that activities to increase metacognitive awareness will produce positive effects on entrepreneurship.

There are various scientific studies that correspond to the findings of this study and that support the results. For instance, Pihie, Bagheri and Sani $(2011,174)$, in a study that they conveyed with university students, emphasize the importance of understanding metacognition in order to increase the entrepreneurial learning of students and thus, their goals to be entrepreneurs. The results by Ling et all. $(2011,15)$ show that entrepreneur students have higher metacognitive awareness than those who are not entrepreneurs, and that entrepreneurial learning produces a positive effect on metacognitive skills of students. As Ling et all. $(2011,15)$ suggest, this situation is reasonable, and entrepreneurship characteristics are prerequisites for high metacognitive skills. Studies show that when those with both entrepreneurship characteristics and high task - master skills have high metacognitive awareness levels, their own actions support the expected results (Vrugt \& Oort, 2008). Moreover, some research findings reveal that metacognitive skills improve the entrepreneurial performance (Haynie, Gregorie \& Shepherd 2004; Haynie \& Shepherd, 2007). The research findings of Ling, Leppiman \& Venesaar (2011) indicate that entrepreneurship courses have immediate influence on metacognitive awareness and on the development of entrepreneurial learning contents and processes at universities. As Mitchell et al (2005) expresses that metacognitive thinking can be applied in an entrepreneurial context; he considers that this metacognitive thinking enables one's own entrepreneurship consciousness to reflect oneself, and it makes understanding and control easier. In this way, he argues that metacognitive thinking leads to entrepreneurial specialization.

It is obvious that one way to increase entrepreneurial thinking is to increase metacognitive awareness. Therefore, it would be of help to provide learning environments that will improve metacognitive awareness of pre-service teachers so as to increase their entrepreneurial tendency. In addition, activities aimed at improving metacognitive awareness can be planned in various courses to support entrepreneurship skills. Besides, the number of courses regarding entrepreneurship and thinking skills at bachelor and postgraduate levels can be increased; and pre-service teachers can be encouraged to select courses with entrepreneurship contents. Furthermore, the relationship between entrepreneurship and other high-order thinking skills can be investigated by researchers. Entrepreneurship characteristics and metacognitive awareness of pre-service teachers can be examined attitudinally on the basis of grade level and field of study.

\section{References}

Aydın, F., \& Coşkun, M. (2011). Geography teacher candidates' metacognitive awareness levels: a case study from 
turkey. Archives of Applied Science Research, 3(2), 551-557.

Baker, L. (2010). Metacognition. International Encyclopedia of Education (Third Edition), 204-210. https://doi.org/10.1016/B978-0-08-044894-7.00484-X

Bakioğlu, B., Alkış, K. M., \& Karamustafaoğlu, O. (2015). Investigation of Prospectıve Teachers' Metacognitive Awareness Levels, Problem Solving Skills and Attitudes Towards Technology. Trakya University Journal of Education, 1(1), 22-33.

Barbosa, S. D., Gerhardt, M. W., \& Kickul, J. R. (2007). The role of cognitive style and risk preference on entrepreneurial self-efficacy and ntrepreneurial intentions. Journal of Leadership and Organizational Studies, 13(4), 86-104. https://doi.org/10.1177/10717919070130041001

Baysal, Z. N., Ayvaz, A., Çekirdekçi, S., \& Malbeleği, F. (2013). An Analysis Of Metacognitive Awareness Of Preservice Elementary Classroom Teachers In Terms Of Various Variables. Marmara University Atatürk Education Faculty Journal of Educational Sciences, 37, 68-81.

Bedel, E. F., \& Çakır, M. (2013). Examining Prospective Pre-School And Biology Teachers' Metacognitive Awareness And Epistemological Beliefs. Marmara University Atatürk Education Faculty Journal of Educational Sciences, 37, 84-98.

Bird, B. J. (1989). Entrepreneurial behavior. Illinois, U.S.A.: Scott Foresman \& Co.

Blakey, E., \& Spence, S. (1990). Developing Metacognition. ERIC Clearinghouse on Information Resources Syracuse. NY. ED 327218.

Brown, A. L. (1980). Metacognitive Development and Reading. R. J. Spiro, B. Bruce \& W. Brewer (Ed) Theoretical Issues in Reading Comprehension. Hillslade, NJ: Lawrence Erbaum.

Çelik, O. (2014). Identification Of The Level Of Enterprising, Knowledge And Ability Of The Students Studying Primary School Teaching And Social Studies Teaching At Faculty Of Education (Unpublished master's thesis) Adnan Menderes University, Aydın, Turkey.

Christensen, L. B., Burke, J. R., \& Turner, L. A. (2014). Research Methods, Design, and Analysis. (Twelfth Edition). Pearson Education, Inc.

Cohen, J. (1988). Statistical Power Analysis for the Behavioral Sciences (Second Edition). Hillsdale, NJ: Erlbaum.

Demircioğlu, H. (2008). Effectiveness of educational events designed for the development of metacognitive behaviours of prospective mathematics teachers (Unpublished PhD Thesis), Gazi University, Ankara, Turkey.

Deniz, D., Küçük, B., Cansız, Ş., \& Akgün, L. (2014). Examining Metacognıtıve Awareness Of Prospectıve Secondary School Mathematics Teachers In Terms Of Some Variables. Kastamonu Education Journal, 22(1), 305-320.

Deveci, İ., \& Çepni, S. (2015). Development of Entrepreneurship Scale Towards Student Teachers: A validity and reliability study. International Journal of Human Sciences, 12(2), 92-112. https://doi.org/10.14687/ijhs.v12i2.3240

Douville, P., \& Pugalee, G. D. (2003). Investigating the Relationship Between Mental Imaging and Mathematical Problem Solving. The Mathematics Education into The 21st Century Project. Proceedings of The International Conference The Decidable and The Undecidable in Mathematics Education Brno, Czech Republic, September.

Duman, B. (2013). The Effect of an Instructional Practice Based on Metacognition upon Teacher Trainees Academic Achievement, Metacognitive Awareness, Achievement Motivation and Critical Thinking Unpublished PhD Thesis), Firat University, Elazığ, Turkey.

Durdukoca, Ş. F. (2012). An analysis of metacognitive awareness levels and self-efficacy beliefs of teachers candidates. 3rd International Conference on New Trends in Education and Their Implications 26-28 April, Antalya, Turkey.

Field, A. P. (2009). Discovering Statistics Using SPSS: And Sex and Drugs and rock 'n' roll (Third edition). London: Sage.

Flavell, J. (1979). Metacognition and Cognitive Monitoring: A New Area of Cognitive-Developmental Inquiry. American Psychologist, 34(10), 906-911. https://doi.org/10.1037/0003-066X.34.10.906

Gelen, İ. (2004). The Effects of Metacognitive Strategies on Attitudes Toward Turkish Course, Reading Comprehension Achievement and Retention. XIII. National Educational Sciences Congress, 6-9 July 2004. İnönü University, Faculty of Education, Malatya, Turkey.

Grégoire, D. A., Corbett, A. C., \& McMullen J. S. (2011). The Cognitive Perspective in Entrepreneurship: An Agenda for Future Research. Journal of Management Studies, 48(6), 1443-1476.

https://doi.org/10.1111/j.1467-6486.2010.00922.x

Gül, Ş., Özay-Köse, E., \& Sadi, Y. S. (2015). Compared To Dıfferent Varıbles Of Prospectıve Bıology Teachers' 
Metacognitive Awareness. Hasan Ali Yucel Journal of Education, 12-1(23), 83-91.

Hacker, D. J., \& Dunlosky, J. (2003). Not All Metacognition Is Created Equal. New Directions for Teaching and Learning, 95, 73-79. https://doi.org/10.1002/tl.116

Hartman, H., \& Stenberg, R. J. (1993). A Broad BACEIS for Improving Thinking. Instructional Science, 21(5), $400-425$. https://doi.org/10.1007/BF00121204

Haynie, J. M., \& Shepherd, D. A. (2007). Exploring the Entrepreneurial Mindset: Feedback and Adaptive Decision-Making. Paper presented at Babson College Entrepreneurship Research Conference (BCERC) and obtained through Social Science Research Network (http://papers.ssrn.com/sol3/papers.cfm?abstract_id=1030014)

Haynie, J. M., Gregorie, D., \& Shepherd, D. A. (2004). Informing entrepreneurial cognition: the role of metacognition and analogical training in strategic decision-making. Social Science Research Network, (http://papers.ssrn.com/sol3/papers.cfm?abstract_id=1768018)

Haynie, J. M., Shepherd, D. A., \& Patzelt, H. (2012). Cognitive Adaptability and an Entrepreneurial Task: The Role of Metacognitive Ability and Feedback. Entrepreneurship Theory and Practice, 36, 237-265. https://doi.org/10.1111/j.1540-6520.2010.00410.x

Hisrich, R. D., \& Peters, M. P. (1998). Entrepreneurship 4th Edition, McGraw Hill, Boston, Mass.

Jager, B., Jansen, M., \& Reezigt, G. (2005). The Development of Metacognition in Primary School Learning Enviroments. School Effectiveness and School Improvement, 16(2), 179-196.

Kacar, M., \& Sarıçam, H. (2015). The Examination of the Relationship between Metacognitive Awareness and Math Anxiety Levels in Pre-Service Primary School Teachers. Trakya University Journal of Education, 5(2), $137-152$.

Karataş, K. (2017). Predicting Teacher Candidates' Self-Directed Learning in Readiness Levels for Terms of Metacognitive Awareness Levels. Hacettepe University Journal of Education, 32(2), 451-465.

Kılınç, E., \& Uygun, M. (2015). Examining The Correlation Between Pre-Service Primary School Teachers' Perception Of Self-Efficacy Toward Life Study Teaching And Their Metacognitive Awareness. Mustafa Kemal University Journal of Graduate School of Social Sciences, 12(29), 1-15.

Kleitman, S., \& Stankov, L. (2007). Self-confidence and metacognitive processes. Learning and Individual Differences, 17(2), 161-173. https://doi.org/10.1016/j.lindif.2007.03.004

Kuiper, R. (2002). Enhancing Metacognition Through The Reflective Use of s-Self-Regulated Learning Strategies. The Journal of Continuing Education in Nursing, 33(2), 78-87.

Larkin, S. (2000). How Can We Discern Metacognition in Year One Children From Interactions Between Students and Teacher. Paper presented at the ESRC Teaching and Learning Research Programme, First Annual Conference University of Leicester, November.

Ling, H., Leppiman, A., \& Venesaar, U. (2011). Exploring the Impact of Entrepreneurship Courses on the Metacognitive Awareness of University Students. Gunnar Prause, Urve Venesaar (eds.) University-Business Cooperation Tallinn 2011. BWV • Berliner Wissenschafts-Verlag.

Ling, H., Liiv, I., Toding, M., \& Venesaar, U. (2011). Metacognitive Awareness and Personal Characteristics of Students: A Case of Estonia. 8th ESU Conference on Entrepreneurship, 1-18.

https://idus.us.es/xmlui/bitstream/handle/11441/58260/Metacognitive\%20Awareness\%20and\%20Personal\%20Cha racteristics $\% 20$ of $\% 20$ Students $\% 20 \mathrm{~A} \% 20$ Case.pdf?sequence=1\&isAllowed=y

Livingston, J. A. (2003). Metacognition: An Overview. (ERIC Document Reproduction Service No. ED 474273 ).

Memduhoğlu, H. B., \& Şahin, M. (2017). An Examination Of The Level Of Entrepreneurship In Teacher's Candidates. Journal of Research in Education and Teaching, 6(1), 297-307.

Mitchell, J. R., Gustavsson, V., Smith, J. B., Davidsson, P., \& Mitchell, R. K. (2005). Thinking about thinking about thinking: Exploring how entrepreneurial metacognition affects entrepreneurial expertise. As presented at: The Babson Research Conference June 10, 2005, Babson College, Wellesley, MA. http://www.ronaldmitchell.org/publications/ttt.pdf

Mitchell, R. K., Busenitz, L., Lant, T., McDougall, P. P., Morse E. A., \& Smith J. B. (2002). Toward a theory of entrepreneurial cognition: Rethinking the people side of entrepreneurship research. Entrepreneurship Theory \& Practice, 27(2), 93-104. https://doi.org/10.1111/1540-8520.00001

Mueller, S., \& Thomas, A. S. (2000). Culture and entrepreneurial potential: a nine country study of locus control and innovativeness. Journal of Business Venturing, 16, 52-62.

Muzyka, D., Koning, A., \& Churchill, N. (1995). On Organization and adaptation: building the entrepreneurial 
corporation. European Management Journal, 13(4), 352-365. https://doi.org/10.1016/0263-2373(95)00029-K

Ocak, G., \& Su, A. (2016). An Evaluation of Entrepreneurship Levels of Prospective Teachers. Asian Journal of Instruction, 4(1), 1-16.

Oktay, A. (1996). İşletme Bilimine Giriş. Trabzon: Derya Bookstore.

Özsoy, G., \& Günindi, Y. (2011). Prospective preschool teachers' metacognitive awareness. Ilkogretim Online, 10(2), 430-440.

Pan, V. L., \& Akay, C. (2015). Examining Teacher Candidates' Entrepreneurship Levels In Terms Of Various Variables. E-Journal of New World Sciences Academy NWSA Education Sciences, 10(2), 125-138. https://doi.org/10.12739/NWSA.2015.10.2.1C0637

Pihie, Z. A. L., Bagheri, A., \& Sani, H. A. (2013). Knowledge of cognition and entrepreneurial intentions: Implications for learning entrepreneurship in public and private universities. Procedia - Social and Behavioral Sciences, 97, 174-181. https://doi.org/10.1016/j.sbspro.2013.10.219

Schraw, G. (1998). Promoting General Metacognitive Awarness. Instructional Science, 26, 113-125. https://doi.org/10.1023/A:1003044231033

Semerci, Ç., \& Elald1, Ş. (2014). The Roles of Metacognitive Beliefs in Developing Critical Thinking Skills. Bartin University Journal of Faculty of Education, 3(2), 317-333. https://doi.org/10.14686/BUEFAD.201428187

Sezgin M. D., \& Akkaya, R. (2012). An Investigation of Pre-service Primary School Mathematics, Science and Classroom Teachers' Metacognitive Awareness in terms of Knowledge of and Regulation of Cognition. Journal of Theoretical Educational Science, 5(3), 312-329.

Sırmac1, N., \& Taş, F. (2016). Teacher Self-Efficacy Perceptions and Metacognitive Learning Strategies of Pre-Service Mathematics Teachers. Hacettepe University Journal of Education, 31(3), 551-563.

Souitaris, V., Zerbinati, S., \& Al-Laham A. (2007). Do entrepreneurship programmes raise entrepreneurial intention of science and engineering students? The effect of learning, inspiration and resources. Journal of Business Venturing, 22, 566-591. https://doi.org/10.1016/j.jbusvent.2006.05.002

Tunca, N., \& Alkın, Ş. S. (2014). The Relationship Between Pre-Service Teachers' Metacognitive Learning Strategies and Academic Self-Efficacy. Anadolu Journal of Educational Sciences International, 4(1), 47-56.

Tuncer, M., \& Kaysi, F. (2013). Evaluation of Prospective Teachers in terms of their Metacognition Thinking Skills. Turkish Journal of Education, 2(4), 44-54.

Tüysüz, C., Karakuyu, Y., \& Bilgin, İ. (2008). Determination of metacognitive levels of teacher candidates Abant İzzet Baysal University Journal of Social Sciences, 2(17), http://dx.doi.org/10.11616/AbantSbe

Ülgen, G. (1997). Education psychology. Ankara: Alkım Publishing.

Vrugt, A., \& Oort, F. J. (2008). Metacognition, Achievement Goals, Study Strategies and Academic Achievement: Pathways to Achievement. Metacognition Learning, 3(2), 123-146. https://doi.org/10.1007/s11409-008-9022-4

Wellman, H. M. (1985). The Origins of Metacognition. D. L. Forrest-Pressley, G.E. MacKinnon and T. Garry Waller (Ed) Matacognition, Cognition, and Human Performance Volume 1 Theorical Perspectives. Orlando, Florida: Academic Press, INC.

Yilmaz, E., \& Sünbül, A. M. (2009). Developing Scale of University Students Entrepreneurship. Selçuk University Journal of Social Sciences Institute, 21, 195-203.

Yokuş, T., \& Yürüdür, F. E. (2015). The Correlation Between Metacognitive Awareness and Self-Efficacy Levels in Pre Service Music Teachers. Turkish Journal of Arts and Social Sciences, 1(1), 22-34.

Yurdakul, B., \& Demirel, Ö. (2011). Contributions of Constructivist Learning Approach to Learners' Metacognitive Awareness. International Journal of Curriculum and Instructional Studies (IJOCIS), 1(1), 71-85.

Zhao, H., Seibert, S. E., \& Hills G. E. (2005). The mediating role of self-efficacy in the development of entrepreneurial intentions. Journal of Applied Psychology, 90(6), 1265-1272. https://doi.org/10.1037/0021-9010.90.6.1265

\section{Copyrights}

Copyright for this article is retained by the author(s), with first publication rights granted to the journal.

This is an open-access article distributed under the terms and conditions of the Creative Commons Attribution license which permits unrestricted use, distribution, and reproduction in any medium, provided the original work is properly cited. 